\title{
The influence of mouse genotype on passive avoidance learning and subsequent concentrations of norepinephrine and serotonin in the hypothalamus and hippocampus
}

\author{
ALLEN C. CHURCH and RICHARD L. SPROTT \\ The Jackson Laboratory, Bar Harbor, Maine 04609
}

\begin{abstract}
Subjects from two strains of mice, C57BL/6J and DBA/2J, were either trained in a passive avoidance task or served as shock controls by receiving footshock at the same time as animals being trained. DBA/2J mice reached the learning criterion significantly faster than C57BL/6J mice. Latencies to leave the "safe" area on the first trial were not significantly different between the two strains. Subsequent analyses of the results of the spectrophotofluorometric assay of norepinephrine and serotonin in the hypothalamic and hippocampal brain regions revealed two effects. First, hippocampal serotonin was higher in DBA/2J mice compared to C57BL/6J mice. Secondly, hypothalamic norepinephrine was higher in DBA/2J mice trained for passive avoidance than in DBA/2J mice that served as shock controls. The results suggest that the higher levels of hippocampal serotonin in DBA/2J mice compared to C57BL/6J mice may predispose the former strain to show better passive avoidance performance under specified circumstances. The observed differences in norepinephrine may have resulted from an interaction between serotonin levels and exposure to the present learning situation.
\end{abstract}

A number of investigators have reported differences in learning performance among various inbred strains of mice (Abeelen, 1966; Bovet, Bovet-Nitti, \& Oliverio, 1969; Collins, 1964; Schlesinger \& Wimer, 1967; Wimer, Symington, Farmer, \& Schwartzkroin, 1968). More recently, the differences in passive avoidance conditioning between the two strains of mice, C57BL/6J and DBA/2J, have been examined in detail (Sprott, 1972; Sprott \& Stavnes, 1975). Sprott (1974) reported that genetic analysis of such differences has indicated that, at a high shock level, passive avoidance performance can be predicted on the basis of a single locus model of genetic inheritance. The value in finding that a given behavior such as passive avoidance performance is determined by a single gene locus inheritance lies in examining the $\mathrm{C} 57 \mathrm{BL} / 6 \mathrm{~J}$ and $\mathrm{DBA} / 2 \mathrm{~J}$ strains and the mating crosses derived from them for physiological characteristics which correlate with the observed differences in learning. Presumably, a single locus difference implies that a difference in one enzyme or in one regulator gene (i.e., control over a related group of

Supported by NIH Grants GM 21469 and MH 12126. We thank Mrs. Jane Harris for assistance. The Jackson Laboratory is fully accredited by the American Association for Accreditation of Laboratory Animal Care. A. C. Church's present address: Department of Pharmacology, University of Pennsylvania Medical School, Philadelphia, Pennsylvania 19104. enzymes) is responsible for the observed differences in learning performance. Thus, use of the C57BL/6J and $\mathrm{DBA} / 2 \mathrm{~J}$ strains may facilitate identification of the physiological mechanisms involved in certain types of learning.

One physiological mechanism which might mediate the strain difference in learning performance is the enzymatic control of brain neurotransmitter levels. Differences have been found in brain catecholamine levels between selected rat lines (Ahtee \& Eriksson, 1975), among inbred mouse strains (Eleftheriou, 1974; Kempf, Greilsamer, Mack, \& Mandel, 1974), and as a consequence of a single gene difference (Lorden, Oltmans, \& Margules, 1975). Unstressed mice of the DBA/2J strain have been reported to have higher serotonin levels in the hippocampal region than $\mathrm{C} 57 \mathrm{BL} / 6 \mathrm{~J}$ mice (Wimer, Norman, \& Eleftheriou 1973). Ciaranello, Lipsky, and Axelrod (1974) have proposed that a single gene difference is responsible for different catecholamine biosynthetic enzyme activities in two inbred mouse sublines. Other investigators have noted differences in catechloamine turnover rates among inbred mouse strains (Eleftheriou, 1971) and between mice differing in only a single gene (Lorden, Oltmans, \& Margules, 1976). Furthermore, Moisset (1977) has found strain differences in norepinephrine (NE) uptake by mouse cerebral cortical synaptosomes. For a more detailed review of the genetic control of catecholamine syn- 
thesis, see Barchas, Ciaranello, Kessler, and Hamburg (1975, pp. 27-62).

The potential involvement of the catecholamines and/or serotonin (5-HT) in modulating learning has been suggested by Kety (1970, pp. 324-336). Work by a number of investigators has supported the notion that the biogenic amines play an important part in both active and passive avoidance learning (Ahlenius, Engel, \& Lundborg, 1975; Allen, Allen, \& Rake, 1974; Dismukes \& Rake, 1972; Fulginiti, Molina, \& Orsingher, 1976; Gallagher, Kapp, Musty, \& Driscoll, 1977; Spanis, Haycock, Handwerker, Rose, \& McGaugh, 1977; Zis, Fibiger, \& Phillips, 1974). In order to determine whether strain differences in biogenic amines might correlate with previously determined strain differences in passive avoidance learning, C57BL/6J and DBA/2J mice were tested for passive avoidance performance and subsequently measured for endogenous levels of brain NE and 5-HT.

\section{METHOD}

\section{Subjects}

A total of $40 \mathrm{DBA} / 2 \mathrm{~J}$ and $40 \mathrm{C} 57 \mathrm{BL} / 6 \mathrm{~J}$ male mice were obtained from the Animal Resources Division of The Jackson Laboratory. All animals were housed 5 to a cage in a vivarium maintained at $22^{\circ} \pm 2^{\circ} \mathrm{C}$ with a $12: 12$-h light-dark cycle. Food and water were provided ad lib. The mice were tested at 4-6 months of age. Out of each strain, 20 mice were randomly assigned to serve as shock controls while the remaining 20 were assigned to the learning situation.

\section{Passive Avoidance Training}

Passive avoidance performance was measured in a $15.3 \times 15.9$ $\times 16.6 \mathrm{~cm}$ clear Plexiglas conditioning chamber with a stainless steel grid floor. The chamber has been described previously (Sprott, 1972). The subjects were tested between 0900 and $1200 \mathrm{~h}$, 5 days/week, in a sound-attenuated testing room adjacent to the vivarium. One learning trial was administered each day. Boli were removed from the conditioning chamber after each trial, and the chamber was thoroughly washed at the end of each day. About $30 \mathrm{~min}$ prior to the start of a daily session, the mice for a particular experimental group were placed in individual, numbered, cardboard cartons. At the beginning of a conditioning trial, a mouse was removed from its carton, and gently lowered onto a $2.5 \times 13.7 \mathrm{~cm}$ black Plexiglas shelf that was mounted on one wall of the chamber. If the subject stepped completely off this shelf, a 1-sec, 5.0-mA scrambled footshock was administered through the grid floor, and the black shelf was simultaneously rotated up against one wall to prevent the subject from jumping back on the shelf. Following a total apparatus exposure time of $1 \mathrm{~min}$, the mouse was returned to its carton for $2 \mathrm{~h}$ and then returned to its home cage. Each subject received one trial each day, 5 days/week, until criterion was reached or until Trial 30. The criterion of learning consisted of a mouse remaining on the shelf for the full 1 -min trial period for 3 consecutive trials. After 30 trials, the experiment was terminated even if the criterion had not been reached by some subjects.

The mice assigned to the shock-control group (SC) were yoked to mice in the learning group (PA: passive avoidance) with respect to shock. In other words, they were concurrently placed in an apparatus that was similar to the passive avoidance apparatus, with the exception that no "safe" shelf was present. When the PA subject received a shock for leaving the shelf, the yoked SC mouse simultaneously received a $4.0-\mathrm{mA}$ scrambled shock. A 4.0-mA shock was used in the SC situation in an attempt to equate the aversiveness of unavoidable, unsignaled shock with shock contingent on behavior. Empirical observations indicated that PA mice anticipating shock were many times airborne before shock onset and therefore would not receive the full shock. All subjects were tested by the same experimenter, who was unaware of the expected results for mice of any genotype.

\section{Preparation of Tissues}

Upon reaching criterion (or 30 trials), a PA subject and the yoked SC animal were sacrificed by decapitation within $5 \mathrm{~min}$. The brain was quickly dissected out and placed on an ice-cold platform. The hypothalamic area was dissected by cutting anteriorly at the optic chiasm, posteriorly at the caudal border of the mammillary bodies, and laterally along the sides of the hypothalamic formation. A shallow undercut produced a hypothalamic sample containing an average of $.54 \pm .14 \mathrm{mg}$ of protein. The hippocampal tissue sample was obtained by making a complete ventrodorsal cut at the level of the anterior edge of the mammillary bodies and a dorsoventral cut at the level of the anterior edge of the superior colliculi. The coronal slice between these two cuts was then placed on a platform cooled by dry ice and allowed to freeze solid. Hippocampal areas were then punched bilaterally using a custom-made crescent-shaped tube $(4.5 \mathrm{~mm}$ long, $1.4 \mathrm{~mm}$ at the widest point). The total sample of hippocampus averaged $1.67 \pm .40 \mathrm{mg}$ of protein. Both types of brain samples were immediately frozen on dry ice following dissection, and stored at $-30^{\circ} \mathrm{C}$. All assays were conducted within 2 weeks of the date of sacrifice.

\section{Neurochemical Analyses}

Simultaneous analysis of endogenous levels of brain NE and 5-HT were performed using a modified version of the fluorescent assay described by Schlumpf, Lichtensteiger, Langemann, Waser, \& Hefti (1974). Briefly, the technique utilizes an acid butanol extraction of the amines from the tissue, aqueous extraction of the amines from the butanol, and formation of fluorophores of NE and 5-HT. An iodine oxidation of NE and an o-phthaldialdehyde reaction with 5-HT were employed as methods for fluorophore formation. Fluorescence was measured using an Aminco-Bowman spectrofluorometer and activation emission wavelengths of 375 , 480 for $5-\mathrm{HT}$ and 405,485 for NE. Tissue sample protein was measured by the method of Lowry, Rosebrough, Farr, and Randall (1951).

\section{RESULTS}

\section{Passive Avoidance Peformance}

The frequency distributions in Figure 1 illustrate the passive avoidance performance of C57BL $/ 6 \mathrm{~J}$ and $\mathrm{DBA} / 2 \mathrm{~J}$ mice. Evaluation of the two distributions using a Student $t$ test confirmed that DBA/2J mice took significantly fewer trials to reach criterion compared to $\mathrm{C} 57 \mathrm{BL} / 6 \mathrm{~J}$ mice $[\mathrm{t}(36)=4.03, \mathrm{p}<.001]$. The average trial to criterion was 9.2 for the $\mathrm{DBA} / 2 \mathrm{~J}$ strain and 21.7 for the C57BL/6J strain. A strain comparison of the latency to leave the shelf on the first trial revealed that the two strains were not significantly different on this measure of activity [C57: $.15 \mathrm{~min}$; DBA: $.26 \mathrm{~min} ; \mathrm{t}(36)=1.75, \mathrm{p}<.1]$. The correlation across strains of Trial 1 latency to step 
down vs. trial to criterion was negative $(-.28)$ but not significant $[\mathrm{t}(36)=1.77, \mathrm{p}<.1]$. Thus, activity in the apparatus, as measured by an animal's tendency to initially step off the "safe" shelf, was not a significant factor in determining passive avoidance performance in this particular paradigm.

\section{Neurochemical Analyses}

The results of the assay for hypothalamic and hippocampal NE in the PA and SC groups are presented in Figure 2. Analyses of variance indicated that neither genotype nor experience significantly influenced NE levels in the hypothalamus or the hippocampus. However, further analyses of hypothalamic NE indicated that, while PA and SC groups did not differ in the C57BL/6J strain, PA animals had higher NE levels than SC animals in the DBA/2J strain $[\mathrm{F}(1,64)=$ $5.85, \mathrm{p}<.02]$. However, no significant correlation of hypothalamic NE with trial to criterion was noted for either genotype. Brain levels of 5-HT are presented in Figure 3. With respect to hypothalamic 5-HT, no significant influence of genotype or experience was

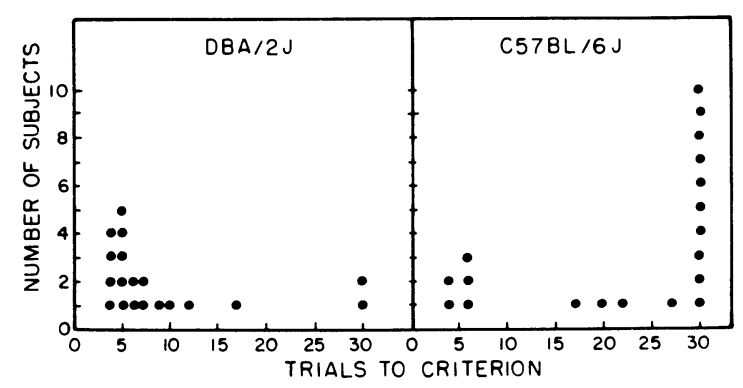

Figure 1. Observed frequency distributions of the performance of $\mathrm{DBA} / 2 \mathrm{~J}$ and $\mathrm{C57BL} / 6 \mathrm{~J}$ mice in a passive avoidance learning situation. Each dot represents a subject that reached criterion on the trial indicated. $N=19$ for each strain.



Figure 2. The influence of passive avoidance training (shaded bars) or shock. alone (unshaded bars) on endogenous levels of brain norepinephrine in DBA/2J and C57BL/6J mice. Number of subjects is given in parentheses.

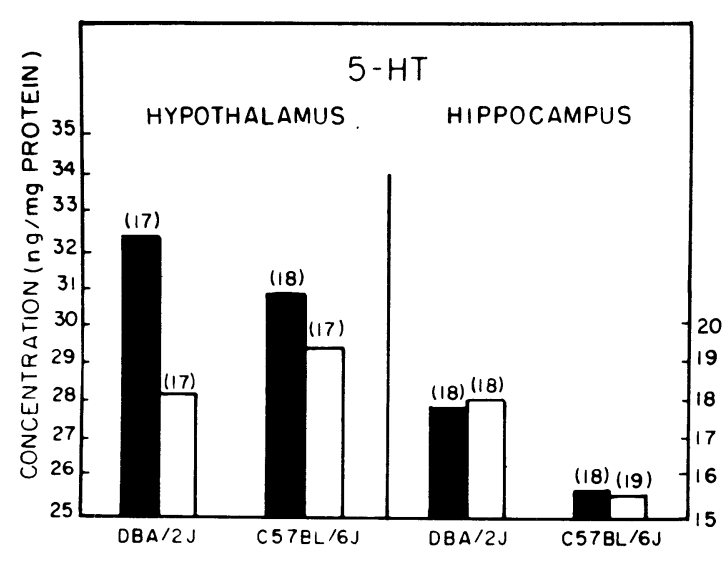

Figure 3. The influence of passive avoidance training (shaded bars) or shock alone (unshaded bars) on endogenous levels of brain serotonin in DBA/2J and C57BL/6J mice. Number of subjects is given in parentheses.

found. However, in the hippocampus, DBA $/ 2 \mathrm{~J}$ mice had higher 5-HT concentrations than C57BL/6J mice $[17.93$ vs. $15.55 \mathrm{ng} / \mathrm{mg}$ protein; $\mathrm{F}(1,69)=7.98$, $\mathrm{p}<.007]$.

\section{DISCUSSION}

The results of the passive avoidance testing confirmed previous studies by demonstrating that, under a specified experimental design, DBA/2J mice learn a passive avoidance task faster than $\mathrm{C} 57 \mathrm{BL} / 6 \mathrm{~J}$ mice (Sprott, 1972, 1974). Analysis of brain chemistry in the PA and SC animals of these two strains has revealed that DBA/2J mice had higher levels of 5-HT in the hippocampus than did C57BL/6J mice. A similar difference has been reported by Wimer et al. (1973), who found that, in untreated mice, the DBA/2J strain had higher hippocampal 5-HT than did the C57BL/6J strain. A recent study by Ramaekers, Rigter, and Leonard (1977) has reported that administration of footshock to rats in a passive avoidance situation is accompanied by a rise in hippocampal 5-HT $24 \mathrm{~h}$ later. In addition, carbon dioxide exposure which blocked passive avoidance learning also blocked the subsequent 5-HT increase. Other work by Harvey, Schlosberg, and Yunger (1976) and Lytle, Messing, Fisher and Phebus (1975) has supported a general role of brain 5-HT in the modulation of reactivity to pain. Both studies report increased responsivity to painful stimuli in animals whose brain 5-HT was reduced. Further support for a role of brain 5-HT in passive avoidance performance has been reported by Allen et al. (1974), who found that reserpine-induced amnesia of a passive avoidance training could be prevented by administration of a 5-HT precursor along with the reserpine. Our results 
suggest that DBA/2J mice with high levels of hippocampal 5-HT may be able to effectively inhibit the arousal produced by stimuli associated with strong footshock. Mice of the C57BL/6J strain have lower 5-HT levels, and thus may not be as well equipped neurochemically as DBA $/ 2 \mathrm{~J}$ mice to control activity levels in the presence of arousal-inducing stimuli.

The finding that DBA/2J mice exposed to a learning situation show higher hypothalamic NE levels than DBA/2J mice who received only shock suggests that this measure may reflect an interaction of higher hippocampal 5-HT with exposure to the PA learning task. Perhaps the higher hippocampal 5-HT of the DBA/2J strain acts to permit an increased noradrenergic response to the PA task. Although no relationship between NE levels and learning performance was found, support for a role of NE in avoidance learning has come from a number of investigators. By inhibiting biosynthesis of brain NE in C57BL/6J mice, Randt, Quartermain, Goldstein, and Anagnoste (1971) were able to restrict learning in a single-trial passive avoidance task. Other investigators have reported NE involvement in shuttle avoidance (Dismukes \& Rake, 1972; Fulginiti et al. 1976), one-way active avoidance (Allen et al., 1974; Spanis et al., 1977), as well as passive avoidance (Gallagher et al., 1977).

Taken as whole, the present results suggest that both NE and 5-HT may be involved in this particular type of passive avoidance task. It is felt that the single locus difference in passive avoidance performance between $\mathrm{C} 57 \mathrm{BL} / 6 \mathrm{~J}$ and $\mathrm{DBA} / 2 \mathrm{~J}$ mice may be related to the observed differences in hippocampal 5 -HT. The higher 5-HT concentrations in the DBA/2J strain allow learning to develop by modulating the arousal-inducing properties of the present task. The difference in NE concentrations in the hypothalamus between the PA and SC groups of the DBA/2J strain is presumed to reflect the permissive action of 5-HT on the neurochemical response to the learning situation. Further testing of the above single-gene hypothesis is planned in order to clearly determine whether 5-HT levels are genetically transmitted in the same fashion as passive avoidance performance.

\section{REFERENCES}

Abeelen, J. H. F. van. Effects of genotype on mouse behaviour. Animal Behavior, 1966, 14, 218-225.

Ahlenius, S., Engel, J., \& Lundborg, P. Antagonism of d-amphetamine of learning deficits in rats induced by exposure to antipsychotic drugs during early postnatal life. NaunynSchmiedeberg's Archives of Pharmacologia, 1975, 288, 185-193.

Ahtee, L., \& ERIKsson, K. Dopaminz and noradrenaline content in the brain of rat strains selected for their alcohol intake. Acta Physiologica Scandinavica, 1975, 93, 563-565.
Allen, C., Allen, B. S., \& Rake, A. V. Pharmacological distinctions between "active" and "passive" avoidance memory formation as shown by manipulation of biogenic amine active compounds. Psychopharmacologia (Berlin), 1974, 34, 1-10.

Barchas, J. D., Ciaranello, R. D., Kessler, S., \& Hamburg, D. A. Genetic aspects of catecholamine synthesis. In R. R. Fieve, D. Rosenthal, \& H. Brill (Eds.), Genetic research in psychiatry, Proceedings of the Annual Meeting of the American Psychopathology Association, 63rd. Baltimore: Johns Hopkins University Press, 1975.

Bovet, D., Bovet-Nitti, F., \& Oliverio, A. Genetic aspects of learning and memory in mice. Science, 1969, 163, 139-144.

Ciaranello, R. D., Lipsky, A., \& Axelrod, J. Association between fighting behavior and catecholamine biosynthetic enzyme activity in two inbred mouse sublines. Proceedings of the National Academy of Sciences USA, 1974, 71, 3006-3008.

Collins, R. L. Inheritance of avoidance conditioning in mice: A diallel study. Science, 1964, 143, 1188-1190.

Dismukes, R. K., \& RAKE, A. V. Involvement of biogenic amines in memory formation. Psychopharmacologia (Berlin), 1972, 23, 17-25.

Eleftheriou, B. E. Regional brain norepinephrine turnover rates in four strains of mice. Neuroendocrinology, 1971, 7, 329-336.

Eleftheriou, B. E. A gene influencing hypothalamic norepinephrine levels in mice. Brain Research, 1974, 70, 538-540.

Fulginiti, S., Molina, V. A., \& Orsingher, O. A. Inhibition of catecholamine biosynthesis and memory processes. Psychopharmacology, 1976, 51, 65-69.

Gallagher, M., Kapp, B. S., Musty, R. E., \& Driscoll, P. A. Memory formation: Evidence for a specific neurochemical system in the amygdala. Science, 1977, 198, 423-425.

Harvey, J. A., Schlosberg, A. J., \& Yunger, L. M. Behavioral correlates of serotonin depletion. Federation Proceedings, 1975, 34, 1796-1801.

Kempf, E., Greilsamer, J., Mack, G., \& Mandel, P. Correlation of behavioral differences in three strains of mice with differences in brain amines. Nature, 1974, 247, 483-485.

KETY, S. S. The biogenic amines in the central nervous system: Their possible roles in arousal, emotion, and learning. In F. O. Schmitt (Ed.), The neurosciences, second study program, New York: Rockefeller University Press, 1970.

Lorden, J. F., Oltmans, G. A., \& Margules, D. L. Central catecholamine levels in genetically obese mice (obob and $\mathrm{dbdb}$ ). Brain Research, 1975, 96, 390-394.

Lorden, J. F., Oltmans, G. A., \& Margules, D. L. Central catecholamine turnover in genetically obese mice (obob). Brain Research, 1976, 117, 357-361.

Lowry, O. H., Rosebrough, N. J., FarR, A. L., \& Randall, R. J. Protein measurement with the Folin phenol reagent. Journal of Biological Chemistry, 1951, 193, 265-275.

Lytle, L. D., Messing, R. B., Fisher, L., \& Phebus, L. Effects of long-term corn consumption on brain serotonin and the response to electric shock. Science, 1975, 190, 692-694.

MorsSET, B. Factors contributing to the modulation of norepinephrine uptake by synaptosomes from mouse brain cortex. Brain Research, 1977, 121, 113-120.

Ramaekers, F., Rigter, H., \& Leonard, B. E. Parallel changes in behaviour and hippocampal serotonin metabolism in rats following treatment with desglycinamide lysine vasopressin. Brain Research, 1977, 120, 485-492.

Randt C. T., Quartermain, D., Goldstein, M., \& Anagnoste, B. Norepinephrine biosynthesis inhibition: Effects on memory in mice. Science, 1971, 172, 498-499.

Schlesinger, K., \& Wimer, R. Genotype and conditioned avoidance learning in the mouse. Journal of Comparative and Physiological Psychology, 1967, 63, 139-141.

Schlumpf, M., Lichtensteiger, W., LangemanN, H., Waser, P., \& Hefti, F. A fluorometric micromethod for the simultaneous determination of serotonin, noradrenaline and dopamine 
in milligram amounts of brain tissue. Biochemical Pharmacology, 1974, 23, 2437-2446.

Spanis, C. W., Haycock, J. W., Handwerker, M. J., Rose, R. P., \& MCGAUGH, J. L. Impairment of retention of avoidance responses in rats by posttraining diethyldithiocarbamate. Psychopharmacology, 1977, 53, 213-215.

SPROTT, R. L. Passive avoidance conditioning in inbred mice: Effects of shock intensity, age, and genotype. Journal of Comparative and Physiological Psychology, 1972, 80, 327-334.

Sprott, R. L. Passive-avoidance performance in mice: Evidence for single-locus inheritance. Behavioral Biology, 1974, 11, 231-237.

SPRotT, R. L., \& Stavnes, K. Effects of situational variables on performance of inbred mice in active- and passive-avoidance situations. Psychological Reports, 1975, 37, 683-692.
Wimer, R. E., Norman, R., \& Eleftheriou, B. E. Serotonin levels in hippocampus: Striking variations associated with mouse strain and treatment. Brain Research, 1973, 63, 397-401.

Wimer, R., Symington, L., Farmer, H., \& Schwartzkroin, P. Differences in memory processes between inbred mouse strains C57BL/6J and DBA/2J. Journal of Comparative and Physiological Psychology, 1968, 65, 126-131.

Zis, A. P., Fibiger, H. C., \& Phillips, A. G. Reversal by L-dopa of impaired learning due to destruction of the dopaminergic nigro-neostriatal projection. Science, 1974, 185, 960-962.

(Received for publication March 29, 1978; revision accepted October 5, 1978.) 